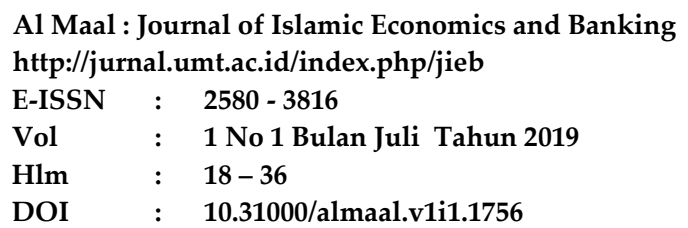

\title{
Pengaruh Non Performing Financing Dan Capital Adequacy Ratio Terhadap Profitabilitas
}

\author{
Rifka Nurul Izzah ${ }^{1, *}$, Ahmad Mulyadi Kosim², Syarifah Gustiawati ${ }^{3}$ \\ 1, 2, 3 Prodi Ekonomi Syariah, Universitas Ibn Khaldun, Bogor, Indonesia \\ *Email: rifkaizzah25@gmail.com
}

\begin{abstract}
This research was conducted with the aim to find out empirically the effect of NPF and CAR on the ROA of Islamic BJB banks simultaneously and partially. The dependent variable in this study is Profitability with Return Of Assets as an indicator. And Independent Variables in this study are NPF and CAR. This research uses quantitative research methods, the population in this study is the Bogor branch of the Islamic bjb bank. In this study using a purposive sampling technique using the financial statements of BJB syariah Bogor in 2010-2018. Data collection through observation is by collecting banking financial statements for 2010 - 2018. The analytical techniques that will be used are Descriptive Statistics Analysis, Classical Assumption Test, Multiple Linear Regression Analysis, and Statistical Hypothesis Test.The results showed that: (1) Non Performing Financing partially had a significant effect on (ROA), with a Sig value of 0.001 (0.001 <0.05). (2) Capital Adequacy Ratio (CAR) partially has a non-significant effect on ROA, with a Sig value of 0.529 (0.529>0.05). (3) Non Performing Financing and Capital Adequacy Ratio have a positive effect on profitability (ROA) with a Sig value of $0.002(0.002<0.05)$.
\end{abstract}

Keywords: CAR; NPF; ROA; Bjb Syariah Bogor

\begin{abstract}
ABSTRAK
Penelitian ini dilakukan dengan tujuan untuk mengetahui secara empiris pengaruh NPF dan CAR terhadap ROA Bank BJB Syariah secara simultan dan parsial. Variabel dependen dalam penelitian ini adalah Profitabilitas dengan Return Of Assets sebagai indikatornya. Dan Variabel Independen dalam penelitian ini adalah NPF dan CAR. Penelitian ini menggunakan metode penelitian kuantitatif. Populasi pada penelitian ini adalah Bank BJB Syariah Cabang Bogor. Dalam penelitian ini menggunakan teknik purposive sampling dengan menggunakan laporan keuangan Bank BJB Syariah Bogor tahun 2010-2018. Pengumpulan data melalui observasi yaitu dengan mengumpulkan laporan keuangan perbankan tahun 2010 - 2018. Teknik analisis yang digunakan adalah Analisis Statistik Deskriptif, Uji Asumsi Klasik, Analisis Regresi Linear Berganda, dan Uji Hipotesis Statistic. Hasil penelitian menunjukan bahwa: (1) Non Performing Financing secara parsial memiliki pengaruh yang signifikan terhadap (ROA), dengan nilai Sig 0,001 (0,001 < 0,05). (2) Capital Adequacy Ratio secara parsial memiliki pengaruh yang tidak signifikan terhadap ROA, dengan nilai Sig 0,529 (0,529 > 0,05). (3) Non Performing Financing dan Capital Adequacy Ratio berpengaruh positif terhadap profitabilitas (ROA) dengan nilai Sig $0,002(0,002<0,05)$
\end{abstract}

Kata kunci : CAR; NPF; ROA; BJB Syariah Bogor 


\section{Pendahuluan}

Keberadaan bank-bank syariah merupakan upaya untuk dapat memenuhi kebutuhan masyarakat yang semakin beragam, masyarakat dapat memilih dan menentukan apakah akan menggunakan jasa perbankan konvensional atau perbankan syariah berdasarkan pertimbangan bisnis yang rasional dan untuk meningkatkan pertumbuhan ekonomi. (Hilman, 2003)

Industri perbankan saat ini sedang berkembang pesat menghadapi masalahmasalah intern bank likuiditas, kelebihan batas kredit, kredit macet bermasalah, dan sebagainya serta masalah ekstren perbankan seperti perubahan peraturan pemerintah, krisis kepercayaan masyarakat yang belum mengetahui dan mengenal dengan baik seluk beluk sistem perbankan syariah dan globalisasi. (Rivai dan Andria, 2007)

Perkembangan di dunia perbankan yang sangat pesat serta tingkat kompleksitas usaha perbankan yang tinggi dapat meningkatkan rasio yang di hadapi oleh bank-bank yang ada di Indonesia. Permasalahan yang ada di Indonesia selanjutnya yaitu depresiasi rupiah, peningkatan suku bunga sertifikat Bank Indonesia (SBI) sehingga menyebabkan meningkatnya kredit bermasalah. Lemahnya kondisi internal bank seperti manajemen yang kurang memadai, pemberian kredit kepada kelompok atau grup usaha sendiri serta modal yang tidak dapat mengcover terhadap risiko - risiko yang di hadapi oleh bank tersebut menyebabkan kinerja bank menurun. (Bagiani, 2014)

Pembiayaan yang di berikan kepada nasabah tidak akan lepas dari risiko terjadinya non performing financing yang pada akhirnya dapat memengaruhi terhadap kinerja bank syariah tersebut. Oleh karena itu, dalam pelaksanaanya bank syariah senantiasa menerapkan prinsip kehati-hatian. (Amir dan Rukmana, 2010)

Analisis faktor utama yang menyebabkan terjadinya non performing financing atas penanaman dana pada perbankan syariah merupakan sesuatu yang sangat penting dan krusial. Hal ini dikarenakan sebagian besar aset bank syariah yaitu dalam bentuk penanaman dana, baik sebagai piutang (murabahah), investasi (musyarakah dan mudharabah) dan aktiva sewa (ijarah) yang semua ini identik dengan risiko, ketidakpahaman atas faktor utama yang menyebabkan terjadinya non performing financing dapat menimbulkan kondisi perbankan syaiah melakukan aktivitas pembiayaan atau penanaman dana tanpa perencanaan matang, analisis kelayakan yang tidak mendalam dan komprehensif, serta mengakibatkan faktor-faktor utama atau signifikan yang dapat menjadi pemicu potensial terjadinya non performing financing. (Amir dan Rukmana, 2010)

Pemahaman yang baik atas faktor utama yang menjadi penyebab terjadinya non perfoming financing akan menjadi modal yang sangat berharga bagi bank yang bersangkutan untuk membangun kebijakan analisis penanaman dana yang komprehensif, prudensial serta memerhatikan berbagai risiko yang intern atas setiap keputusan penanaman dana. Selain itu, kebutuhan tersebut semakin dirasakan karena dana yang disalurkan oleh bank syariah akan selalu mengandung risiko kredit macet. Oleh karena itu, analisis faktor yang signifikan sebagai penyebab terjadinya "kredit macet" merupakan kebutuhan mendasar bagi perbankan syariah. (Amir dan Rukmana, 2010)

Dana yang di salurkan olah bank syariah kepada nasabah mengenai kewajiban penyediaan modal minimum bank umum, bank wajib menyediakan modal minimum sesuai profil risiko. Penyediaan modal minimum bank umum ditetapkan paling rendah 
sebesar $8 \%$. Besarnya modal suatu bank akan berpengaruh terhadap mampu atau tidaknya suatu bank secara efisien menjalankan kegiatannya. (Simatupang dan Denis, 2016)

Apabila modal yang dimiliki oleh bank tidak mampu menyerap kerugian yang tidak dapat terhindarkan, maka bank tidak dapat mengelola seluruh kegiatannya secara efisien. Semakin tinggi CAR sebuah bank, maka semakin tinggi kemampuan bank dalam menanggung risiko dari aktiva yang berisiko. (Aulia, 2016)

Bank dengan Capital Adequacy Ratio (CAR) yang cukup besar akan mampu mendukung pengembangan operasi dan kelangsungan hidup bank serta menanggung risiko-risiko yang ditimbulkan termasuk di dalamnya risiko kredit sehingga akan mampu meningkatkan profitabilitas bank. (Almunawwarah, 2018)

Dilihat dari profitabilitasnya dan efisiensi operasional saat ini non - interest income merupakan faktor utama yang menunjang kinerja perbankan Indonesia, namun demikian, hanya 30\% dari pendapatan tersebut yang berasal dari fee based income, sedangkan sisanya berasal dari aktivitas trading yang berfluktuasi. (Rivai dan Andria, 2007)

Profitabilitas menggambarkan kemampuan perusahaan dalam mendapatkan laba melalui semua kemampuan dan sumber yang ada seperti kegiatan penjualan, kas, modal, jumlah karyawan, jumlah cabang, dan sebagainya. Bank Indonesia telah menetapkan salah satu ukuran profitabilitas suatu bank adalah Return on Asset (ROA). ROA penting bagi bank karena ROA digunakan untuk mengukur efektivitas perusahaan di dalam menghasilkan keuntungan dengan memanfaatkan aktiva yang dimilikinya. Perusahaan dengan profitabilitas yang baik menunjukkan perusahaan mempunyai prospek yang baik, perusahaan akan mampu mempertahankan kelangsungan perusahaan dalam jangka panjang. (Nur dan Sayu, 2017)

Pada penelitian ini variabel dependen yang digunakan yaitu profitabilitas. Rasio profitabilitas yaitu rasio yang memiliki tujuan guna untuk melihat kinerja suatu perusahaan dalam menghasilkan keuntungan dalam periode tertentu, sehingga memberikan hasil terkait dengan tingkat efektifitas manajemen dalam melakukan kegiatan operasionalnya. (Almunawwarah, 2018)

Perkembangan dan persaingan industri perbankan yang semakin ketat mengharuskan setiap bank untuk memiliki strategi yang tepat dalam mencapai keunggulan bersaing. Dalam hal ini, bank syariah harus mampu mengembangkan perusahaannya. Salah satunya dengan cara melalui perancangan strategi yang baik dan unggul. Berdasarkan latar belakang diatas, peneliti ingin mengetahui apakah ada pengaruh dari Rasio Non Performing Financing dan Capital Adequacy Ratio terhadap profitabilitas (ROA).

Menurut Meidina dan Marliana (2018) bahwa nilai CAR, NPF dan FDR secara parsial berpengaruh signifikan terhadap profitabilitas. Nilai CAR dan NPF berpengaruh negatif terhadap profitabilitas, Karena nilai CAR negatif sedangkan hipotesis yang diajukan adalah positif dapat disimpulkan H1 ditolak. CAR pada bank syariah di Indonesia pada tahun 2009-2016 yang tinggi tidak menyebabkan profitabilitas yang tinggi. Jika dilihat dari kondisi empiris dari obyek penelitian, maka akan tampak bahwa sebagian besar bank syariah mempunyai CAR di atas $8 \%$ dan memiliki rata-rata CAR sebesar $14,8 \%$. Hipotesis dalam penelitian ini menyebutkan bahwa NPF memiliki pengaruh negatif terhadap profitabilitas. Hal ini menunjukkan bahwa semakin besar NPF 
akan berdampak pada penurunan Profitabilitas. Penelitian tingkat NPF perbankan syariah masih tergolong rendah, yaitu 4,08\%. Sehingga perlu adanya kehati-hatian pihak bank dalam menjalankan fungsinya. Risiko berupa kesulitan pengembalian pembiayaan oleh debitur dengan jumlah yang cukup besar dapat mempengaruhi kinerja bank. Pada hipotesis dinyatakan bahwa FDR berpengaruh positif dan signifikan terhadap Profitabilitas. Dari hasil penelitian diperoleh nilai beta untuk variabel FDR bernilai positif. Hal ini menunjukkan bahwa semakin besarNPF akan berdampak pada peningkatan Profitabilitas. Dilihat dari variabel pada penelitain terdahulu, maka pada penelitian ini hanya menggunakan dua variabel yaitu CAR dan NPF.

Menurut Aulia dan Prasetiono (2014) bahwa CAR merupakan rasio besarnya modal dasar yang harus dipenuhi oleh bank. Modal merupakan salah satu faktor penting bagi perbankan dalam melakukan kegiatan operasinya, mengembangkan usaha bisnis, serta mengantisipasi adanya risiko kerugian. FDR menggambarkan perbandingan antara besarnya pinjaman atau pembiayaan yang diberikan pada nasabah dengan jumlah dana yang dihimpun oleh bank syariah. Semakin tinggi dana yang disalurkan bank dalam bentuk pembiayaan, maka semakin tinggi pula kemampuan bank dalam memberikan pinjaman. Hal ini berdampak pada peningkatan pendapatan, sehingga keuntungan perbankan syariah semakin meningkat. Namun, apabila pembiayaan yang disalurkan oleh bank tersebut rendah, maka dapat dikatakan bahwa tingkat likuiditas bank terlalu tinggi sehingga hal ini menimbulkan tekanan terhadap pendapatan bank berupa tingginya biaya pemeliharaan kas yang menganggur. Nilai rata-rata (mean) NPF pada penelitian ini ialah sebesar 20,5933\% pada periode 2009-2013. Hal ini berarti bahwa rata-rata pembiayaan bermasalah pada bank sampel mencapai 20,5933\% dari seluruh pendanaan yang dilakukan oleh bank. dalam penelitian ini menyatakan bahwa BOPO berpengaruh negatif terhadap ROE. Hasil penelitian ini menunjukkan bahwa pada variabel BOPO diperoleh nilai t sebesar $-11,389$. Nilai t signifikansi pengujian sebesar 0,000. Nilai signifikansi lebih besar dari 0,05 menunjukkan bahwa BOPO berpengaruh secara signifikan terhadap ROE. Persamaan variabel yang di gunakan dalam penelitian ini adalah NPF dan CAR, dan perbedaanya adalah variabel FDR, dan BOPO, dan untuk mengukur profitablitasnya menggunakan ROE dan pada penelitian ini menggunakan ROA.

Adapun tujuan penelitian ini adalah pertama, untuk menganalisis pengaruh Non performing Financing (NPF) terhadap profitabilitas (ROA) pada Bank BJB Syariah Bogor periode 2010 -2018. Kedua, untuk menganalisis pengaruh Capital Adequacy Ratio (CAR) terhadap profitabilitas (ROA) pada Bank BJB Syariah Bogor periode 2010 - 2018. Ketiga, untuk menganalisis pengaruh Non performing Financing (NPF) dan Capital Adequacy Ratio (CAR) terhadap profitabilitas (ROA) pada Bank BJB Syariah Bogor periode $2010-2018$

\section{KAJIAN LITERATUR Pengertian Perbankan}

Menurut Karnaen A. Perwaatmadja bank syariah merupakan bank beroperasi sesuai dengan prinsip-prinsip Islam, bank dengan tata cara dengan operasinya mengikuti ketentuan-ketentuan syairah Islam. Salah satu unsur yang harus dijauhi Salam muamalah Islam merupakan praktik- praktik yang mengandung unsur riba. (Firdaus, 2007)

Menurut Amin Aziz (2007) juga berpendapat bahwa Bank Islam merupakan perbankan yang menggunakan sistem dan operasi berdasarkan syariah Islam. Hal ini 
berarti, operasional bank syariah harus sesuai dengan tuntunan Al - Quran maupun Hadist. Yaitu menggunakan sistem bagi hasil dan imbalan lainnya sesuai dengam syariah islam.

Dalam Al-Quran, istilah bank pernah disebutkan secara eksplisit, tetapi menurut Arifin jika yang di maksud merujuk pada suatu yang memiliki unsur seperti struktur, manajemen, fungsi, hak dan kewajiban, maka semua itu disebutkan dengan jelas seperti zakat dan shodaqoh, ghanimah, bai, dan sebagainya, atau segala sesuatu yang memiliki fungsi atau peran tertentu yang dilaksanakan dalam rangka kegiatan ekonomi. (Firdaus, $2007: 2$ )

Dari beberapa pengertian di atas dapat disimpukan bahwa yang dimaksud dengan bank Islam yaitu sebuah lembaga keuangan yang berfungsi sebagai penghimpun dana dan menyalurkan kepada masyarakat. dimana sistem, tata cara, dan mekanisme kegiatan usahanya berdasarkan pada syariat islam. yaitu Al - Quran dan hadist.( Firdaus, 2007)

Sedangkan simpanan di bank menurut jumhur fukaha kontemporer sebagaimana dijelaskan oleh Waluya (2017) bahwa mereka memandangnya sebagai akad utang piutang. Oleh karena itu wadiah di bank dibangun atas dasar yad dhamanah, bukan yad amanah.

\section{Non Performing Financing (NPF)}

Dalam berbagai peraturan yang di terbitkan bank Indonesia tidak dijumpai pengertian "Pembiayaan Bermasalah". Begitu juga istilah Non Performing financing (NPF) dalam peraturan-peraturan yang di terbitkan Bank Indonesia. Namum dalam setiap statistik Perbankan Syariah yang di tebitkan oleh Direktorat Perbankan Syariah Bank Indonesia dapat di jumpai istilah Non Performing financing (NPF) yang di artikan sebagai "pembiayaan Non Lancar mulai dari kurang lancar sampai dengan sangat macet". (Djamil, 2012)

Pembiayaan masalah tersebut, dari segi produktivitasnya yaitu kaitannya dengan kemampuannya menghasilkan pendapatan bank, sudah berkurang atau menurun dan bahkan mungkin sudah tidak ada lagi. Bahkan dari segi bank, sudah tentu mengurangi pendapatan, memperbesar biaya pencadangan, yaitu PPAP (peyisihan penghapusan aktiva profuktiv), sedangkan dari segi nasinonal, mengurangi kontibusinya terhadap pembangunan dan pertumbuhan ekonomi. (Djamil. 2012)

Besarnya NPF yang baik adalah dibawah 5\%. NPF diukur dari rasio perbandingan antara kredit bermasalah terhadap total kredit yang diberikan. Semakin besar NPF akan memperkecil keuntungan/profitabilitas bank karena dana yang tidak dapat ditagih mengakibatkan bank tidak dapat melakukan pembiayaan pada aktiva produktif lainnya. Hal ini mengakibatkan pendapatan bank menjadi berkurang sehingga profitabiltas perbankan akan terganggu. (Almunawarah dan Rina. 2018)

\section{Capital Adequacy Ratio (CAR)}

Menurut Wardiah (2013), CAR merupakan rasio kecukupan modal bank atau kemampuan bank dalam permodalan yang ada untuk menutup kemungkinan kerugian dalam perkreditan atau perbandingan surat-surat berharga. 
Menurut Hasibuan (2004), CAR merupakan rasio keuangan yang memberikan indikasi apakah permodalan yang ada telah memadai (adequate) untuk menutup risiko kerugian akan mengurangi modal.

Menurut Khaerul (2013), CAR merupakan kewajiban penyediaan modal minimum yang harus selalu dipertahankan oleh setiap bank sebagai suatu proporsi tertentu dari total aktiva tertimbang risiko ( ATMR).

Modal suatu bank pada dasarnya dinilai berdasarkan pemenuhan bank yang bersangkutan terhadap ketentuan pemenuhan modal minum (KPMM). Pemenuhan ketentuan tersebut dihitung dari rasio modal terhadap ATMR. KPMM sebesar 8\% diberi predikat "sehat" dengan nilai kredit sebesar 81 , dan untuk setiap kenaikan sebesar $0,1 \%$ dari pemenuhan sebesar 8\% ditambah 1 sampai sebesar maksimum 100. Sementara itu, untuk pemenuhan KPMM sebesar 8\% sampai 7,9\% diberi predikat kurang sehat dengan nilai kredit 65, dan untuk kenaikan sebesar 0,1\% dari pemenuhan KPMM sebesar 7,9\% nilai kredit dikurangi 1 dengan minimum 0. (Rivai, $2014: 210$ )

Rasio CAR menunjukan kemampuan dari modal untuk menutup kemungkinan kerugian atas kredit yang diberikan beserta kerugian pada investasi surat-surat berharga. CAR menurut standar BIS (Bank For International Settlements) minimum sebesar $8 \%$. Jika kurang dari itu akan di kenakan sanksi oleh Bank Sentral. (Wardiah, 2013 : 297)

\section{Pengertian profitabilitas (ROA)}

Profitabilitas merupakan suatu kemampuan bank dalam menghasilkan laba selama periode tertentu dengan total aktiva atau modal yang dimilikinya yang dinyatakan dalam presentase. (Riyanto, 2008)

Bank yang sehat adalah bank yang dilihat dari Profitabilitas atau rentabilitas yang terus meningkat di atas standar yang ditetapkan. Profitabilitas merupakan kemampuan bank dalam menghasilkan laba secara efektif dan efisien. (wijaya, 2005)

Profitabilitas adalah kemampuan suatu bank dalam memperoleh laba ditunjukkan oleh keuntungan yang dihasilkan. (Simorangkir, 2004)

Tingkat Keseluruah Return Of Asset (ROA) merupakan rasio Profitabilitas yang penting bagi bank karena digunakan untuk mengukur efektifitas perusahaan untuk menghasilkan laba dengan memanfaatka total aktiFanya. (Munawir, 2007)

Menurut Hasibuan (2001), ROA merupakan perbandingan (rasio) laba sebelum pajak (earning before tax/EBT) selama 12 bulan terakhir terhadap rata-rata volume usaha dalam periode yang sama.

\section{Cara Mengukur profitabilitas Return on Asset (ROA)}

Return On Assets (ROA) digunakan untuk mengukur Profitabilitas bank karena Bank Indonesia sebagai pembina dan pengawas perbankan lebih mengutamakan nilai Profitabilitas suatu bank yang diukur dengan aset yang dananya sebagian besar dari dana simpanan masyarakat. Semakin besar ROA suatu bank, semakin besar pula tingkat keuntungan yang dicapai bank, dan semakin baik posisi bank tersebut dari segi penggunaan aset (Dendawijaya, 2009) 
Teknik untuk menghitung Return On Assets (ROA) sebagai berikut:

$$
R O A=\frac{\text { Laba Sebelum Pajak }}{\text { Rata }- \text { rata aktiva produktif }} \times 100 \%
$$

\section{Capital Adequacy Ratio (CAR)}

Rasio kecukupan modal (Capital Adequacy Ratio) merupakan faktor penting bagi bank dalam rangka pengembangan usaha dan menampung risiko kerugian (Khaerul Umam, 2013)

Bank Indonesia menetapkan modal (Capital Adequacy Ratio/CAR),yaitu kewajiban penyediaan modal minimum yang harus selalu dipertahankan oleh setiap bank sebagai suatu proporsi tertentu dari Aktiva Tertimbang Menurut Resiko (ATMR), atau secara matematis:

$$
C A R=\frac{\text { Modal }}{A T M R} \times 100 \%
$$

\section{Non Performing Financing (NPF)}

Pengelolaan pembiayaan sangat diperlukan oleh bank, mengingat fungsi pembiayaan sebagai penyumbang pendapatan terbesar bagi bank syariah. Tingkat kesehatan pembiayaan (Non Performing Financing) ikut mempenaruhi pencapaian laba bank. Rumus yang digunakan untuk mencari NPF adalah sebagai berikut:

$$
\mathrm{NPF}=\frac{\text { Jumlah Pembiayaan Bermasalah }}{\text { Total pembiayaan }}
$$

\section{Metode Penelitian \\ Jenis Penelitian}

Jenis penelitian pada skripsi ini menggunakan penelitian kuantitatif, dengan data yang di gunakan adalah data sekunder dan primer. Data sekunder untuk semua variabel dan data rasio-rasio keuangan yang terdapat pada laporan keuangan Bank BJB Syariah Cabang Bogor selama tahun 2010 - 2018. Data primer berupa data-data seputar latar belakang Bank BJB syariah, profil dan produk bjb syariah Bogor.

Metode kuantitatif digunakan untuk menghitung besarnya tingkat profitabilitas bank, khususnya Return on Asset (ROA) pada Bank BJB Syariah Bogor.

\section{Tempat dan Waktu penelitian}

Penelitian mengenai pengaruh Non Performing Financing (NPF) dan Capital Adequacy Ratio (CAR) terhadap Profitabilitas ini dilakukan pada Bank BJB Syariah Cabang Bogor, waktu penelitian dilakukan pada bulan Februari sampai bulan Juni 2019. 


\section{Populasi dan Sampel}

Populasi Merupakan objek atau subjek yang mempunyai kualitas dan karakteristik tertentu yang ditetapkan oleh peneliti untuk dipelajari dan kemudian ditarik kesimpulannya. (Sugiono, 2018). Populasi pada penelitian ini adalah Bank BJB Syariah Cabang Bogor tahun 2010-2018.

Sampel merupakan bagian jumlah dan karakteristik yang dimiliki oleh populasi tesebut. Bila populasi besar, dan peneliti tidak mungkin mempelajari semua yang ada pada populasi. (Sugiono, 2018)

Dalam penelitian ini menggunakan teknik purposive sampling. Purposive sampling merupakan teknik penarikan sampel yang dilakukan berdasarkan karakteristik yang ditetapkan terhadap elemen populasi target yang disuaikan dengan tujuan atau masalah penelitian. ( Tanjung dan Abrista, 2013). Dengan menggunakan laporan keuangan bank bjb syariah cabang Bogor yang telah di publikasikan disitus BI (Bank Indonesia) dan Otoritas Jasa Keuangan.

\section{Teknik Pengumpulan data}

Teknik yang digunakan dalam penelitian ini melalui observasi tersamar, dalam hal ini, peneliti dalam melakukan pengumpulan data, bahwa ia sedang melakukan penelitian, jadi sampel yang diteliti mengetahui sejak awal sampai akhir tentang aktivitas peneliti. (Sugiono, 2015)

Pengumpulan data melalui observasi yaitu dengan mengumpulkan laporan keuangan perbankan tahun 2010 - 2018 dari laman bank yang telah dipublikasikan. Penulis juga mengumpulkan data dari buku Anual Report yang dipinjamkan dari pihak Bank BJB syariah Bogor.

Dalam menyusun karya ilmiah ini, peneliti menggunakan sumber data sekunder dan primer. Sumber data Sekunder adalah tulisan mengenai penelitian orang lain yang disajikan dalam bentuk komentar atau tinjauan pustaka oleh orang yang tidak secara langsung mengamati atau ikut serta terlibat. (Tanjung dan Abrista, 2013). Data tersebut diperoleh dalam bentuk laporan keuangan yang mempunyai relevansi dengan peneltian ini.

\section{Teknik Analisis Data}

Analisis data diartikan sebagai upaya data yang sudah tersedia kemudian diolah dengan statistik dan dapat digunakan untuk menjawab rumusan masalah dalam penelitian. Dengan demikian, teknik analisis data dapat diartikan sebagai cara melaksanakan analisis terhadap data, dengan tujuan mengolah data tersebut untuk menjawab rumusan masalah. (Sujarweni, 2018)

Analisis data dalam penelitian ini menggunakan program SPSS, untuk mencapai tujuan dalam penelitian ini, maka teknik analisis yang akan digunakan adalah sebagai berikut: Analisis Statistik Deskriptif, Uji Asumsi Klasik dan Analisis Regresi Linear Berganda.

Analisis regresi linier berganda digunakan untuk menguji pengaruh antara variabel independen Non Performing Financing (NPF) dan Capital Adequacy Ratio $(C A R)$ terhadap dependen Profitabilitas (ROA). 


\section{Hasil dan Pembahasan Analisis Statsitik Deskriptif}

Analisis statistik deskriptif bertujuan menjelaskan deskripsi data dari masingmasing varibel yang digunakan dalam penelitian. Deskripsi data meliputi nilai minimum, nilai maksimum, nilai rata-rata dan standard devirsiation dari setiap variabel. Variabel Dependen dalam penelitian ini adalah profitabilitas (ROA) Bank BJB Syariah. Sedangkan variabel independen dalam penelitian ini adalah Non Performing Financing (NPF), dan Capital Adequacy Ratio (CAR).

\section{Return On Asset (ROA)}

Return On Asset (ROA) adalah salah satu rasio Profitabilitas yang merupakan variabel dependen dalam penelitian ini. Berikut ini adalah data statistik deskriptif variabel ROA pada Bank BJB Syariah Bogor periode 2010-2018.

Tabel 1 Hasil Statistik Deskriptif Variabel ROA periode 2010-2018

\begin{tabular}{ll}
\hline Keterangan & Return of asset (ROA) \\
\hline Nilai minimum & $-8,09$ \\
Nilai maksimum & 1,23 \\
Nilai rata - rata & $-1,1156$ \\
Standar deversiasi & 3,36614 \\
\hline
\end{tabular}

Sumber: data output SPSS Statistics

Variabel dependen ROA mempunyai nilai minimum -8,09 dan nilai maksimum 1,23. Sementara nilai standard deviation sebesar 3,36614 dan nilai rata - rata (mean) 1,1156. Hal ini menunjukan bahwa secara statistik, selama periode penelitian rasio ROA Bank bjb syariah ada yang tidak memenuhi standar karena ada rasio yang memiliki nilai berada dibawah 8\%. Sementara standard deviation yang masih lebih kecil jika dibandingkan nilai mean-nya menunjukan bahwa simpangan data pada ROA relatif baik. Nilai rata-rata (mean) yang lebih besar dibandingkan nilai standard deviation menunjukan bahwa data terdistribusi dengan baik.

\section{Non Performing Financing (NPF)}

Non Performing Financing (NPF) merupakan variabel independen pada penelitian ini. Berikut ini adalah statistik deskriptif varianel NPF pada Bank BJB Syariah periode 2010-2018: 
Tabel 2 Hasil Statistik Deskriptif Variabel NPF periode 2010-2018

\begin{tabular}{ll}
\hline Keterangan & Non Performing Financing $(N P F)$ \\
\hline Nilai minimum & 1,38 \\
Nilai maksimum & 22,04 \\
Nilai rata - rata & 7,4278 \\
Standar deversiasi & 7,43600 \\
\hline
\end{tabular}

Sumber: data output SPSS Statistics

Variabel NPF mempunyai nilai minimum 1,38 dan nilai maksimum 22,04. Sementara nilai standard deviation sebesar 7,43600 dan nilai rata-rata (mean) 7,4278. Hal ini menunjukan bahwa secara statistik, selama periode penelitian rasio NPF pada Bank bjb syariah belum memenuhi standar yang ditetapkan oleh Bank Indonesia yakni NPF dibawah 5\%. Sementara standard deviation yang masih lebih besar jika dibandingkan nilai mean-nya menunjukan bahwa simpangan data pada NPF relatif belum baik. Niai rata-rata (mean) yang lebih kecil dibandingkan standard deviation menunjukan bahwa data belum terdistribusi dengan baik

\section{Capital Adequacy ratio (CAR)}

Capital Adequacy ratio (CAR) merupakan variabel independen pada penelitian ini. Berikut ini adalah statistik deskriptif varianel CAR pada Bank bjb Syariah periode 2010-2018:

\begin{tabular}{ll}
\hline Keterangan & Capital Adequacy ratio (CAR) \\
\hline Nilai minimum & 15,83 \\
Nilai maksimum & 31,43 \\
Nilai rata - rata & 21,2111 \\
Standar deversiasi & 5,96487 \\
\hline
\end{tabular}

Tabel 3 Hasil Statistik Deskriptif Variabel CAR periode 2010-2018

\section{Sumber: data output SPSS Statistics}

Variabel independen CAR mempunyai nilai minimum 15,83 dan nilai maksimum 31,43. Sementara nilai standard deviation sebesar 5,96487 dan rata-rata (mean) 21,2111. Hal ini menunjukan bahwa secara statistik, selama periode penelitian rasio CAR Bank bjb syariah telah memenuhi standar yang ditetapkan Bank Indonesia yaitu minimal $8 \%$. Sementara standard deviation yang masih lebih kecil dibandingkan nilai meannya menunjukan bahwa simpangan data CAR relatif baik. Nilai rata-rata (mean) yang lebih besar dibandingkan nilai standard deviation menunjukan bahwa data terdistribusi dengan baik. 


\section{Uji Asumsi Klasik}

\section{Uji normalitas}

Uji normalitas data digunakan untuk mengetahui apakah data pada variabel terdistribusi normal atau tidak. Uji statistik yang dapat digunakan untuk menguji normalitas adalah dengan uji statistik Non Parametric Kolmogrov-Smirnov.

Tabel 4 Hasil Uji Normalitas

\begin{tabular}{|c|c|c|}
\hline \multicolumn{3}{|c|}{ One-Sample Kolmogorov-Smirnov Test } \\
\hline & & Unstandardized \\
\hline & & Residual \\
\hline \multicolumn{2}{|l|}{$N$} & 9 \\
\hline \multirow[t]{2}{*}{ Normal Parametersa, $b$} & Mean &, 0000000 \\
\hline & Std. Deviation & 1,22590731 \\
\hline \multirow[t]{3}{*}{ Most Extreme Differences } & Absolute &, 161 \\
\hline & Positive &, 094 \\
\hline & Negative &,- 161 \\
\hline \multicolumn{2}{|l|}{ Test Statistic } &, 161 \\
\hline \multicolumn{2}{|l|}{ Asymp. Sig. (2-tailed) } & $, 200 c, d$ \\
\hline \multicolumn{3}{|c|}{ a. Test distribution is Normal. } \\
\hline \multicolumn{3}{|c|}{ b. Calculated from data. } \\
\hline \multicolumn{3}{|c|}{ c. Lilliefors Significance Correction. } \\
\hline \multicolumn{3}{|c|}{ d. This is a lower bound of the true significance. } \\
\hline
\end{tabular}

Berdasarkan hasil uji normalitas menggunakan metode Kolomogrof Smirnov diketahui hasil signifikansi dari uji normalitas sebesar 0,200 > 0,005 dengan demikian diinterprestasikan bahwa uji tes normalitas pada penelitian ini adalah terdistribusi normal.

\section{Uji Multikolineritas}

Uji multikolinieritas bertujuan untuk menguji apakah model regresi ditemukan adanya korelasi antar variabel independen. Model regresi yang baik seharusnya tidak terjadi korelasi antar variabel independen.

Multikolinieritas dapat dilihat dari :

a) Nilai tolerance dan lawannya

b) Variance Inflation Factor (VIF)

c) Satu model dapat dikatakan bebas multikolinieritas jika nilai TOL > 0,1 atau jika memiliki nilai VIF $<10$ 


\begin{tabular}{|c|c|c|}
\hline \multirow[b]{2}{*}{ Model } & \multicolumn{2}{|c|}{ Collinearity Statistics } \\
\hline & Tolerance & $V I F$ \\
\hline \multicolumn{3}{|c|}{ (Constant) } \\
\hline$N P F$ & ,745 & 1,342 \\
\hline$C A R$ & ,745 & 1,342 \\
\hline
\end{tabular}

Dari tabel diatas dapat dilihat bahwa setiap variabel independen memiliki nilai TOL > 0,1 dan masing-masing variabel tersebut juga memiliki nilai VIF < dari 10. Jadi dapat dipastikan bahwa penelitian ini terbebas dari masalah multikolinearitas.

\section{Uji AutoKorelasi}

Uji autokorelasi bertujuan menguji apakah dalam model regresi linier terdapat korelasi antara kesalahan pengganggu pada periode $t$ dengan kesalahan pengganggu pada periode t-1 (sebelumnya). Cara untuk mendeteksi ada tidaknya autokorelasi adalah dengan uji Durbin-Watson ( $D W$ test). Hasil perhitungan uji Durbin-Watson yang ada akan dibandingkan dengan nilai tabel dari Durbin-Watson. Pada penelitian ini, hasil pengujian autokorelasi dapat dilihat pada tabel berikut:

Tabel 6 Hasil Uji Autokorelasi

\begin{tabular}{|c|c|c|c|c|c|}
\hline \multicolumn{6}{|c|}{ Model Summaryb } \\
\hline & & & Adjusted $R$ & Std. Error of & Durbin- \\
\hline Model & $R$ & $R$ Square & Square & the Estimate & Watson \\
\hline 1 & ,931a & ,867 &, 823 & 1,41556 & 3,033 \\
\hline
\end{tabular}

Berdasarkan hasil perhitungan uji Durbin Watson nilai yang diperoleh adalah sebesar 3,033, dimana nilai tersebut berada diantara -2 dan +2 , maka dapat dinyatakan bahwa data penelitian ini tidak terdapat masalah autokorelasi.

\section{Analisis Regresi linier Berganda}

Dari hasil uji asumsi klasik diatas dapat disimpulkan bahwa data yang digunakan dalam peneitian ini terdistribusi secara normal serta tidak memiliki masalah uji normalitas, multikolinearitas, dan autokorelasi sehingga memenuhi persyaratan untuk melakukan analisis regresi berganda serta melakukan pengujian setiap hipotesis.

Hasil analisis regresi linier berganda yang di lakukan melalui analisis statistik dengan menggunakan Software SPSS Versi 25 for windows maka diperoleh persamaan regresi sebagai berikut : 
Tabel 7 Hasil Uji Regresi Linier Berganda

Coefficients $^{a}$

\begin{tabular}{lll}
\hline \multirow{2}{*}{ Model } & \multicolumn{2}{l}{ Unstandardized Coefficients } \\
\cline { 2 - 3 } 1 (Constant) & $B$ & Std. Error \\
NPF & 3,571 & 2,452 \\
CAR &,- 445 &, 078 \\
\hline
\end{tabular}

Dependen Variabel : Profitabilitas (ROA)

sumber : output data yang diolah pada SPSS Statistics

Berdasakan hasil analisis regresi linier yang dilakukan melalui analisis Statistics dengan menggunakan Software SPSS Versi 25 for windows, dengan memperhatikan angka yang berada pada kolom Unstandardzed Coefficients Beta, maka disusun persamaan regresi sebagai berikut :

$$
\mathrm{Y}=3,571+0,445+0,065
$$

Dari persamaan regresi diatas maka dapat kita interprestasikan beberapa hal antara lain sebagai berikut:

a) Nilai kostanta adalah 3, 571, yang berarti jika Non Performing Financing (NPF) dan Capital Adequacy Ratio (CAR) bernilai nol, maka Profitabilitas (ROA) bernilai Konstanta 3,571

b) Nilai Koefisien regresi Variabel NPF bernilai 0,445 yang berarti jika variabel NPF mengalami kenaikan sebesar satu satuan sementara, maka Profitabilitas (ROA) akan meningkat sebesar 0,445 dengan asumsi variabel lainnya tetap.

c) Nilai koefisien variabel CAR diperoleh nilai 0,065 yang berarti jika variabel CAR mengalami kenaikan sebesar satu satuan sementara, maka Profitabilitas (ROA) akan meningkat sebesar 0,065 dengan asumsi variabel lainnya tetap.

\section{Pengujian Hipotesis}

\section{Uji Simultan F}

Uji F digunakan untuk mengetahui bersama-sama antar variabel independen yang ada berpengaruh terhadap variabel dependen, dapat diketahui hipotesisnya sebagai berikut :

Keterangan :

a) Jika signifikansi $<0,05$ maka Ho diterima

b) Jika signifikansi $>0,05$ maka Ha ditolak 
Rifka Nurul Izzah, Ahmad Mulyadi Kosim \& Syarifah Gustiawati

Tabel 8 Hasil Uji F

\begin{tabular}{|c|c|c|c|c|c|c|}
\hline$\overline{A N O V A}$ & & & & & & \\
\hline & & Sum of & & & & \\
\hline Model & & Squares & $D f$ & Mean Square & $F$ & Sig. \\
\hline 1 & Regression & 78,625 & 2 & 39,312 & 19,619 & ,002 \\
\hline & & & & & & $b$ \\
\hline & Residual & 12,023 & 6 & 2,004 & & \\
\hline & Total & 90,647 & 8 & & & \\
\hline
\end{tabular}

a. Dependent Variable: ROA

b. Predictors: (Constant), CAR (X2), NPF (X1)

\section{Sumber : Output data yang di olah pada SPSS Statistics}

Berdasarkan output diatas dapat dilihat nilai $\mathrm{F}$ hitung hasil pengolahan data sebesar 19,619 dan nilai signifikansi sebesar 0,002<0,05 artinya data tersebut signifikan. sehingga dapat disimpulkan bahwa Non Performing financing (ROA) dan Capital Adequacy Ratio (CAR) berpengaruh terhadap profitabilitas (ROA). Ini berarti Ho ditolak dan Ha diterima.

\section{Uji Signifikansi Parsial (Uji-t)}

Uji T digunakan untuk mengetahui apakah secara parsial Non Performing Financing (NPF) dan Capital Adequacy Ratio (CAR) berpengaruh secara signifikan terhadap Profitabilitas (ROA). Untuk mengetahui hasilnya dapat dilihat dari kolom (sig) dalam tabel dibawah ini :

Keterangan :

a) Jika signifikansi $<0,05$ maka Ho diterima

b) Jika signifikansi > 0,05 maka Ha ditolak

\begin{tabular}{|c|c|c|c|c|c|c|}
\hline \multicolumn{7}{|c|}{ Coefficients $^{a}$} \\
\hline \multirow[b]{3}{*}{ Model } & & \multicolumn{2}{|c|}{ Unstandardized } & \multicolumn{3}{|l|}{ Standardized } \\
\hline & & \multicolumn{2}{|c|}{ Coefficients } & \multicolumn{3}{|l|}{ Coefficients } \\
\hline & & $B$ & Std. Error & Beta & $T$ & Sig. \\
\hline 1 & (Constant) & 3,571 & 2,452 & & 1,456 & , 196 \\
\hline & $N P F$ &,- 445 & ,078 &,- 984 & $-5,714$ & ,001 \\
\hline & $C A R$ &,- 065 & 097, &,- 115 & -668 & ,529 \\
\hline
\end{tabular}

Tabel 9 Hasil Uji T

Sumber : output data SPSS Statistics 
a) Pengaruh NPF terhadap ROA

Berdasarkan hasil uji $\mathrm{T}$ diatas diperoleh nilai t hitung variabel NPF sebesar 5,715 dengan nilai signifikasi sebesar $0,001<0,05$ artinya signifikan. Dan dapat disimpulkan bahwa NPF secara parsial memiliki pengaruh yang signifikan terhadap (ROA). Arah pengaruh bertanda positif menunjukan bahwa NPF yang rendah cenderung membuat ROA naik. Ini berarti Ho ditolak dan ha diterima.

b) Pengaruh CAR terhadap ROA

Berdasarkan uji $\mathrm{T}$ diatas diperoleh $\mathrm{t}$ hitung variabel CAR sebesar -0,668 dengan nilai signifikansi sebesar 0,529>0,05 artinya tidak signifikan. Dan dapat disimpulkan bahwa CAR secara parsial memiliki pengaruh yang tidak signifikan terhadap ROA. Arah pengaruh bertanda negatif menunjukan bahwa CAR yang tinggi tidak membuat ROA meningkat. Ini berarti Ho diterima dan ha ditolak.

\section{Uji Koefisien Determinasi $\left(R^{2}\right)$}

Uji Koefisien Determinasi $\left(R^{2}\right)$ digunakan untuk mengukur sejauh mana kemampuan model dalam menerangkan variabel independen. Nilai koefisien determinasi yang semakin mendekati satu maka variabel independen yang ada dapat memberikan hampir semua informasi yang dibutuhkan untuk memprediksi variabel dependen, dan begitu juga sebaliknya. Nilai $R^{2}$ tersebut dapat dilihat pada tabel dibawah ini :

Tabel 10 Hasil Uji Koefisien

\begin{tabular}{lllll}
\hline \multicolumn{3}{c}{ Model Summaryb } & \multicolumn{3}{c}{ Adjusted $R$} & \multicolumn{1}{c}{ Std. Error of the } \\
\hline \multirow{3}{*}{$\begin{array}{llll}\text { Model } \\
1\end{array}$} & $R$ & $R$ Square & Square & Estimate \\
1 &, $931 a$ &, 867 &, 823 & 1,41556 \\
\hline \multicolumn{5}{c}{ Determinasi $\boldsymbol{R}^{2}$}
\end{tabular}

a. Predictors: (Constant), CAR, NPF

b. Dependent Variable: ROA

Berdasarkan hasil uji koefisien determinasi, dapat dilihat bahwa nilai koefisien determinasi $\left(R^{2}\right)$ sebesar 0,867 . Nilai ini menunjukan bahwa sebesar $82,3 \%$ Profitabilitas (ROA) dipengaruhi oleh variasi dari kedua variabel independen yang digunakan, yaitu NPF dan CAR sedangkan sisanya sebesar dijelaskan oleh variabel NPF dan CAR sebesar $17,7 \%$ dipengaruhi oleh faktor-faktor lain yang tidak diteliti pada penelitian ini.

\section{Pengaruh Non Performing Financing terhadap Profitabilitas (ROA)}

Hasil penelitian dapat diketahui NPF memiliki pengaruh yang positif dan signifikan terhadap ROA. dimana hasil uji parsial diperoleh nilai t hitung variabel NPF sebesar -5,715 dengan nilai signifikasi sebesar 0,001 $<0,05$ artinya signifikan. Arah pengaruh bertanda positif menunjukan bahwa NPF yang rendah cenderung membuat ROA naik dan sebaliknya.

Hasil penelitian ini menunjukan bahwa NPF berpengaruh terhadap ROA, maka Bank bjb syariah harus berhati - hati dalam mengelola dan menyalurkan pembiayaan 
untuk mengurangi jumlah pembiayaan yang bermasalah. Pengaruh positif yang ditunjukan oleh NPF mengindikasikan bahwa semakin rendah pembiayaan bermasalah, maka akan menaikan ROA pada bank.

\section{Pengaruh Capital Adequacy Ratio (CAR) terhadap Profitabilitas (ROA)}

Hasil penelitian dapat diketahui variabel CAR memiliki pengaruh positif dan tidak signifikan terhadap ROA. Dimana perhitungan uji secara parsial diperoleh diperoleh $\mathrm{t}$ hitung sebesar $-0,668$ dengan nilai signifikansi sebesar 0,529>0,05. Ini berarti bahwa semakin tinggi tingkat kecukupan pemenuhan modal (CAR) suatu bank tidak terjadi tolak ukur keberhasilan manajemen bank dalam memperoleh profit yang tinggi.

Tidak signifikannya CAR terhadap ROA, hal ini bisa terjadi dikarenakan peraturan BI yang mengharuskan setiap bank untuk menjaga CAR dengan ketentuan minimal $8 \%$. Sehingga para pemilik bank menambah modal bank dengan menyediakan dana untuk mengantisipasi skala usaha berupa expansi pembiayaan yang diberikan agar CAR dapat memenuhi ketentuan BI. Atau bisa juga dikarenakan bank cenderung untuk menginvestasikan dananya dengan hati-hati sehingga CAR tidak berpengaruh banyak terhadap profitabilitas bank.

\section{Pengaruh NPF dan CAR terhadap Profitabilitas (ROA)}

Hasil pengujian menunjukan bahwa NPF dan CAR nilai F hitung hasil pengolahan data sebesar 19,619 dan nilai signifikansi sebesar 0,002 < 0,05 artinya data tersebut signifikan. sehingga dapat disimpulkan bahwa Non Performing financing (ROA) dan Capital Adequacy Ratio (CAR) berpengaruh terhadap profitabilitas (ROA).

\begin{tabular}{lll}
\multicolumn{2}{c}{ Tabel 11 Hasil Uji Hipotesis } \\
\hline No & Hipotesis & Hasil uji t-test \\
\hline 1. & NPF berpengaruh signifikan positif & \\
& terhadap profitabilitas (ROA) & Diterima \\
2 & CAR berpengaruh signifikan negatif & \\
& terhadap Profitabilitas (ROA) & Ditolak \\
3 & NPF dan CAR berpengaruh signifikan & \\
& terhadap Profitabilitas (ROA) & Diterima \\
& & \\
\hline
\end{tabular}

Sumber : Data Sekunder yang diolah

\section{KESIMPULAN}

Penelitian ini bertujuan untuk mengetahui pengaruh Non Performing Financing (NPF) dan Capital Adequacy Ratio (CAR) terhadap Profitabilitas (ROA) pada Bank BJB Syariah Bogor tahun 2010 - 2018. Berdasarkan hasil analisis yang telah dilakukan dengan menggunakan SPSS For Windows Versi 25. Maka dapat disimpulkan bahwa:

Pertama, berdasarkan hasil analisis yang dilakukan variabel NPF memiliki pengaruh yang positif dan signifikan terhadap ROA. Dimana diperoleh nilai t hitung 
variabel NPF sebesar -5,715 dengan nilai signifikasi sebesar 0,001 $<0,05$ artinya signifikan. Arah pengaruh bertanda positif menunjukan bahwa NPF yang rendah cenderung membuat ROA naik dan sebaliknya.

Kedua, berdasarkan hasil analisis yang dilakukan variabel CAR memiliki pengaruh positif dan tidak signifikan terhadap ROA. Dimana diperoleh t hitung sebesar $-0,668$ dengan nilai signifikansi sebesar $0,529>0,05$. Ini berarti bahwa semakin tinggi tingkat kecukupan pemenuhan modal (CAR) suatu bank tidak terjadi tolak ukur keberhasilan manajemen bank dalam memperoleh profit yang tinggi.

Ketiga, Berdasarkan analisis yang dilakukan variabel NPF dan CAR secara simultan berpengaruh secara signifikan terhadap ROA Bank BJB Syariah Bogor tahun 2010-2018. Hal tersebut dibuktikan dengan hasil uji-F hitung hasil pengolahan data sebesar 19,619 dan nilai signifikansi sebesar 0,002 <0,05 artinya data tersebut signifikan. sehingga dapat disimpulkan bahwa Non Performing financing (ROA) dan Capital Adequacy Ratio (CAR) berpengaruh terhadap profitabilitas (ROA).

\section{REFERENSI}

Aulia, Farrashita. 2016. Pengaruh CAR, FDR, NPF dan BOPO Terhadap Profitabilitas (Return On Equity). Skripsi : S1 Universitas Diponegoro

Agus, Widarjono. 2010. Analisis Statistika Multivariat Terapan, Yogyakarta : UUP STIM YKPN.

Almunawwarah, Medina dan Rina. 2018. Pengaruh Car, NPF dan FDR Terhadap Profitabilitas Bank Syariah di Indonesia. Jurnal ISSN Hal 3, Vol. 2 No. 1

Bagiani, Yonira Alifiah. 2014. Pengaruh CAR, NPL, BOPO dan LDR Tehadap Profitabilitas ROA Pada Perusahaan Perbankan yang Terdaftar di Bursa Efek Indonesia. Skripsi S1 Universitas Negri Yogyakarta, 2014.

Djamil, Faturrahman. 2012. Penyelesaian Pembiayaan Bermasalah Di Bank Syariah, Jakarta: Sinar Grafika

Denda Wijaya. 2003. Manajemen Perbankan, Jakarta : Ghalia Indonesia.

Firdaus NH, Muhammad dan Sofiniyah Ghufron. 2007. Konsep dan Implementasi Bank Syariah, Jakarta: Renaisan Anggota IKAPI

Hilman, Iman. 2003. Perbankan Syariah Masa Depan, Jakarta: senayan abadi publishing.

Kuncoro, Mudrajat. 2015. Metode Kuantitatif, Yogyakarta : Unit Penerbit dan Percetakan (UUP) STIM YKPN.

Muslimin, Karra. 2013. Statistik Ekonomi, Makasar : Alanudin

Munawir.2007. Analisis Laporan Keuangan, Yogyakarta : Liberty.

Nur, Rossana Oktavia Subagiono dan sayu Kt. Sutrisna. 2017. Pengaruh LDR, Car, NPL, BOPO Terhadap Profitabilitas Lembaga Pengkreditan Desa di Kota Denpasar. Jurnal ISSN Vol. 6, No, 10, 2017

Nirmala, Sari. 2014. Pengaruh Loan to deposit Ratio (LDR), dan Capital Adequacy Ratio (CAR) Terhadap Profitabilitas (ROA) pada PT. Bank Mandiri (Persero). Skripsi : Universitas Islm Negri Alamuddin Makasar

Riyanto. 2008. Dasar-Dasar Pembelanjaan Perusahaan, Yogyakarta: BPFE. 
Rifka Nurul Izzah, Ahmad Mulyadi Kosim \& Syarifah Gustiawati

Rivai, Veithzal dan Andria Permata. 2007. Bank dan Financial Institution Management, Jakarta: PT Raja Grafindo Persada.

Sugiono. 2018. Metode Penelitian Bisnis. Bandung : Alvabeta

Sujarweni, Wiratna. 2018. Metodelogi Penelitian Bisnis dan Ekonomi, Yogyakarta : Pustaka Baru Press

Simorangkir. 2004. Lembaga Keuangan Bank dan Non Bank, Jakarta: Fakultas Ekonomi UI.

Tanjung, Hendri dan Abrista devi. 2013. Metodologi Penelitian Islam. Pondok Gede Bekasi : Gramata publishing.

Waluya, Atep Hendang. 2017. The Essence Of Al Wadi'ah Al Mashrifiyyah. Journal of Islamic Economics Lariba. Vol 3 Issue 2. Hlm. 105

Wardiah, Mia Lasmani. 2013. Dasar-Dasar Perbankan. Bandung: Pustaka Setia.

Wahid, Sulaiman. 2004. Analisis Regresi Menggunakan SPSS, Contoh Kasus dan Pemecahannya, Yogyakarta: Andi 